DOI https://doi.org/10.18551/rjoas.2018-06.44

\title{
DYNAMICS OF DEGREE OF BEEF CATTLE MARKET CONCENTRATION IN KUPANG OF EAST NUSA TENGGARA, INDONESIA
}

\author{
Nendissa Doppy Roy* \\ Graduate School of Agriculture, Faculty of Agriculture, University of Brawijaya, Malang \& \\ Agribusiness, Faculty of Agriculture, University of Nusa Cendana, Kupang, Indonesia
}

\author{
Anindita Ratya, Hanani Nuhfil, Muhaimin Abdul Wahib \\ Faculty of Agriculture, University of Brawijaya, Malang, Indonesia
}

*E-mail: bramroy213@gmail.com

\begin{abstract}
Beef cattle is a strategic commodity, economically, socially and culturally for the people of Nusa Tenggara Timur and Indonesia. This the study aims to measure the dynamics of the degree of market concentration of beef cattle sales in Kupang, Nusa Tenggara Timur for 2014-2017. The results show the dynamics of the concentration of beef cattle market is relatively moderate, shown by the consignment (CR4 and HHI) that fluctuate in 2014-2017. Fluctuating trends of market concentration indicates horizontal business integration between firms and have implications for price regulation by oligopoly, consequently an inefficient market. This research contributes to market participants and stakeholders, so the government's role in managing the marketing system of beef cattle is more efficient.
\end{abstract}

\section{KEY WORDS}

Beef cattle, market concentration, $\mathrm{CR} 4, \mathrm{HHI}$, oligopoly.

The Indonesian government continues to encourage the acceleration of national beef cattle production by various programs, one of which is a program that is the mainstay is the Mandatory Bantu Special Cattle Efforts, which is proclaimed since 2017. The main objective to overcome the lack of consumption of beef in the country that continues to increase from year on year, and now its shortcomings are overcome by the way of imports. Meanwhile, domestic beef production continues to decrease compared to the increase of meat requirement. Domestic beef production the system is still relying on people's livestock business. One of the regions with the fifth largest population of livestock population are East Nusa Tenggara, which is $5.76 \%$ and 4 th shipment of beef cattle out of Nusa Tenggara Timur province (Direktorat Jenderal Peternakan dan Kesehatan Hewan Kementan, 2017).

Nusa Tenggara Timur Livestock Service Data for the last 5 years, Nusa Tenggara Timur has sent beef cattle to be sold outside of Nusa Tenggara Timur between 50,000 and 70,000 heads each year with the main objective of Java and Kalimantan (the Livestock Service Office of Nusa Tenggara Timur, 2017). In 2017 the number of cattle that sent as many as 60,360 tail, as much as $82.49 \%$ comes from the island of Timor and Kupang regency.

Sales of cattle outside Nusa Tenggara Timur are often constrained by relatively high price fluctuations following price fluctuations in Java Island as a center for meat production and consumption. A quota policy per year that can send cattles out of Nusa Tenggara Timur is also a constraint. In addition, the distance of long cattle delivery (sea transport transports traveled 5-6 days journey), as well as the cattle trading system that has not been efficient. Another obstacle is the traditional cattle business system (loose system), as well as the pattern of sales by farmers according to the economic needs of the family.

The cattle marketing system above leads to sales volume and pricing being difficult to manage, by all market participants (breeders, traders, and consumers). Every market participant, especially a cattle delivery company, will use the profit-making strategy of the cucumber by improving its performance. One way to improve the company's performance is 
to try to gain market share to increase the degree of market concentration. But the market that high degree of concentration because entrepreneurs use all means to reap the benefits so that there will be market inequality (inefficient market). The weakest position in the face of the high degree of market concentration is the producers of the breeders in Kupang is very large. Because the main livelihood of the population of Kupang Regency is raising cattle other than farming dating. It is important to know the dynamics of the degree of change in the concentration of the beef cattle market.

The purpose of this study is to measure the dynamics of the concentration of beef cattle market from 2014-2017. The results of this study are expected to be a consideration for market participants and governments in dealing with inefficient and volatile market mechanisms.

\section{METHODS OF RESEARCH}

The market concentration is the distribution of the number of different intercompany product sales. The market concentration shows how much of the total sales in the market for a commodity is distributed to certain companies. To measure the concentration of industrial markets, the number of firms and firm size needs to be taken into account (Kazemzadeh and Sheikh, 2015).

The concentration of the market does not happen by chance but because there are parliamentary forces that occur around it that do not change over time, Therefore, in order to measure market concentration it is necessary to calculate the market share of each company. Market share is one indicator in determining the market power of a company. To measure market share should be done by census all companies (Anindita and Baladina, 2017 ) involved in product sales. Market share is measured by the ratio of the volume of sales by one company to the overall volume of product sales in the market. Market share is higher the market power is higher. This gives effect to the level of competition in the market. The market share is formulated:

$$
\begin{aligned}
& S i=\sum_{i=1}^{n} n i / N \times 100 \% \\
& S i=\text { market share of the firm to } i \\
& n i=\text { the sales volume of the firm to } \mathrm{i} \\
& N=\text { overall sales volume in the market }
\end{aligned}
$$

Measure the degree of market concentration of beef cattle sales using two approaches, namely Concentration Ratio for Biggest Four (CR4) and Hirschman-Herfindahl Index (HHI). Many measuring tools can be done to measure the level of market concentration. All of these measuring tools are not guaranteed to be the most perfect gauge. However, the most commonly used widely and more reliably is CRN and $\mathrm{HHI}$. This is in line with Naldi and Flamini, (2014) that the concentration index that is often used to measure the level of competition in the industry are $\mathrm{HHI}$ and $\mathrm{CR} 4$ because it is considered the most established Special for $\mathrm{HHI}$ for example often used by the US Department of Justice and Federal Reserve (Rhoades, (1993) and is also used by the Indonesian Commission for Business

Supervision and Competition (KPPU).
Measurement of the degree of the market, concentration to be observed is the dynamics of CR4 and HHI changes in beef cattle sales market from 2014 - 2017 in Kupang regency of Nusa Tenggara Timur.

Measurement Concentration Ratio for Biggest Four (CR4). The concentration of ration for a given number of firms ( $R C n)$ will give an idea of the role of $n$ companies in the industry. The highest concentration ratio of 4 firms (CR4) is most often used in measurement (Gwin, 2001), although there is no standard provision as to how much should be included in CRn calculations (Lipczynski, et al 2005).

Concentration The ratio for Biggest Four (CR4) is an analytical tool to determine the degree of concentration of the four largest market shares of a market area (Anindita and Baladina, 2017). If the available data is limited then simply know the four CR4 companies 
that have the largest market share only. After gaining the largest market share of 4 companies, then add them up. The formula for measuring CR4 in this study:

$$
\begin{gathered}
\mathrm{CR} 4=\sum_{i=1}^{4} \mathrm{Si} \text { whether CR4 = S1 + S2 + S3 + S4 } \\
\text { Si }=\text { Market Share }
\end{gathered}
$$

The main disadvantage of this index is that differences in market structure may not emerge: a market in which each of the four largest firms exist with the same percentage of share (Naldi and Flamini, 2014a) although the level of competition is very different for the four firms of size the same than four companies of different sizes. In addition CR4 does not consider the entire market, but only a limited number of companies. The CR4 classification is associated with the market structure then by Gwin, (2001) concentrations categorized:

\author{
Minim if $\mathrm{CR} 4=0$, perfect competition market, monopolistic competition \\ Low if $0<\mathrm{CR} 4<40 \%$, effective or monopolistic competition \\ Medium to lower if $40 \% \leq$ CR $4<60 \%$, monopolistic competition or loose oligopoly \\ Upper medium if $60 \% \leq \mathrm{CR} 4<90 \%$, tight oligopoly competition \\ High if CR4 $\geq 90 \%$, effective nomopoly \\ Maximum Concentration CR4 $=100 \%$, perfect monopier
}

The Hirschman - Herfindahl Index $(\mathrm{HHI})$. The measurement of $\mathrm{HHI}$ is a refinement of CRn measurements, as it provides a more outward view of the market structure. Therefore it should be in the know and measured all market share of existing companies in the industry. $\mathrm{HHI}$ calculations require full knowledge of the overall market share, (Naldi and Flamini, $2014 \mathrm{~b}$ ), also mentioned that $\mathrm{HHI}$ is an indicator of the degree of competition in the market. The $\mathrm{HHI}$ analysis tool aims to determine the degree of sales / sales concentration from a market area, so that it can know the general picture of the balance of strength of bargaining position between the seller to the buyer (Anindita and Baladina, 2017). How to calculate HHI is the sum of quadratic market share of each shipping company of existing beef cattle. Formulated as follows:

$$
\begin{aligned}
& \mathrm{HHI}=\sum_{i=1}^{n} S i^{2} \text { whether } \mathrm{HHI}=S i^{2}+S i^{2}+S i^{2}+\ldots+S i^{2} \\
& \mathrm{Si}=\text { Market Share } \\
& \text { The HHI criteria by Anindita and Baladina (2017) categorize in concentration: } \\
& \text { High if the HHI between } 1,800-10,000 \text {, the monopoly market; } \\
& \text { Medium if the HHI between } 1000-1800 \text {, oligopoly market; } \\
& \text { Low if HHI between } 0-1000 \text {, perfect competition market. }
\end{aligned}
$$

\title{
RESULTS AND DISCUSSION
}

The results based on official data on the Livestock Service Office of Nusa Tenggara Timur, which obtained a cattle shipment permit, there are 89 companies, but the reality is not all companies directly involved in the delivery/sale of inter-island livestock. So the calculation result of the market concentration of $\mathrm{CR} 4<0,15$ and $\mathrm{HHI}<500$ or very low concentration, can be classified as perfect competition market. However, this issue is only a pseudo concentration, not significantly happening in the field. Findings and observations in the field there are inter-company transactional practices in seizing cattle delivery quota. Some companies do business integration to seize market share. On the other hand of the 89 companies, there are several subsidiaries of several dominant companies.

The result of observation through an in-depth interview in some companies and data search company found that the real company that sends cattle from Kupang out of the province of Nusa Tenggara Timur 2014 there are 8 companies total sales of cattle out of Nusa Tenggara Timur 13,038 tail, in 2015 there are 11 companies with total sales15. 626 tails and 2016 there are 11 companies total cattle sales 15,850 cattles and in 2017 there are 12 companies with total sales of 19,510 cattles. The transaction of beef cattle sales is conducted between inter-island traders in Kupang with big traders in Jakarta and other 
islands. The amount of transactions for cattle delivery outside Nusa Tenggara Timur occurs after there is a price agreement and the amount requested and the limit of cattle quota allowed to be delivered also in that year. Every year the Local Government issues a policy on the number of cattle quota concessions that the island escapes to Nusa Tenggara Timur. The purpose of the policy is to protect the cattle population to continue to grow while maintaining the sustainability of production.

Table 1 - Dynamics of Degree of Market Concentration of Beef Cattle Sales Year 2014-2017

\begin{tabular}{|c|c|c|c|c|c|}
\hline Year & Number of companies & CR4 & Si & HHI & Market Structure \\
\hline 2014 & 0,708 & 0,708 & 70,854 & $1.621,381$ & Strict oligopoly \\
\hline 2015 & 0,616 & 0,616 & 61,596 & $1.223,217$ & Strict oligopoly \\
\hline 2016 & 0,509 & 0,509 & 50,946 & $1.209,834$ & Monopolistic or loose Oligopoly \\
\hline 2017 & 0,601 & 0,601 & 60,140 & $1.193,901$ & Strict oligopoly \\
\hline
\end{tabular}

Source: Secondary Data Processed, 2018.

In table 1 shows that there is a dynamics of changes in market concentration is quite volatile from 2014-2017. In terms of CR4 value, market share and HHI are highest in 2014, then decline in 2015 but still categorized in the Oligopoly market structure. Then in 2016 the value of concentration (CR4) decreases again to 0.509 and is classified in monopolistic market structure or loose oligopoly. While in 2017 the market concentration of CR4 and HHI again increased. The dynamics of the density of the cattle market concentration occurs along with the change in the number of cattles that are delivered and the difference in the number of companies that sell livestock out of Nusa Tenggara Timur. But the change remains at the level of concentration that can provide opportunities for some companies with dominant market share to dominate the sales market.

The market conditions in oligopoly competition are loose to tight then it can easily dominant companies regulate price and product quality. The results of observation on the purchase of cattle by traders and traders traders between islands in the breeders do not use scales to measure the weight of the cattle by way of assessing by looking at the physical appearance of cattles. This method is very detrimental to the breeder because the estimate is usually under the actual weight of the cattle. While inter-island traders and traders use scales to measure weight in transactions. Thus the quality of the product is determined by the trader not the farmer. The same is pointed out by Kazemzadeh and Sheikh, (2015); Bosena (2011), that on a strong oligopolistic market the company can easily determine the price and quality of the product. The price in the concentrated market (monopoly / duopoly) is found to be approximately $30 \%$ higher than the competitive market with seven or eight companies (Singh and Zhu, (2008). Therefore the company is always trying to shrink market share by increasing the degree of market concentration in order to increase the profit or performance of the company. The effort to seize market concentration is closely related to creating market structure and improving company performance Mohamed, et al (2015), market structure through CR4 gives effect to market performance and market behavior. et al. (2017) in Regional State, Ethiopia, found that the market concentration ratio indicates a strong oligopoly beef market structure in the study area, indicating that few traders share the majority market share and companies earn more profit than producer.

The market conditions in oligopoly competition are loose to tight then it can easily dominant companies regulate price and product quality. The results of observation on the purchase of cattle by traders and traders between islands in the breeders do not use scales to measure the weight of the cattle by way of assessing by looking at the physical appearance of cattles. This method is very detrimental to the breeder because the estimate is usually under the actual weight of the cattle. While inter-island traders and traders use scales to measure weight in transactions. Thus the quality of the product is determined by the trader, not the farmer. The same is pointed out by Kazemzadeh and Sheikh, (2015); Bosena (2011), that on a strong oligopolistic market the company can easily determine the price and quality of the product. The price in the concentrated market (monopoly/duopoly) is found to be approximately $30 \%$ higher than the competitive market with seven or eight 
companies (Singh and Zhu, (2008). Therefore the company is always trying to shrink market share by increasing the degree of market concentration in order to increase the profit or performance of the company. The effort to seize market concentration is closely related to creating market structure and improving company performance Mohamed, et al (2015), the market structure through CR4 gives effect to market performance and market behavior. et al. (2017) in Regional State, Ethiopia, found that the market concentration ratio indicates a strong oligopoly beef market structure in the study area, indicating that few traders share the majority market share and companies earn more profit than a producer.

The existence of the dynamics of changes in the degree of market concentration indicates that the sales market of cattle is very dependent on the amount of distribution of quota delivery by the government. Every company is always looking for a strategy in seizing the quota or market share set by the government. The a strategy that the company does in seizing market share is by doing transactional cooperation between companies or by means of business integration horizontally.

Dynamics market concentration is getting more dynamic because most companies have a sales license and get the shipping quote, but do not have cattle stock for sale. While there are entrepreneurs who have a large stock of cattle but get a quota or limited shipping quotas from the local government. To overcome this, companies with large stocks of cattle are forced to buy their quota in companies that do not own cattle at varying quote prices, between 25,000 - 100,000 IDR/tail, while still using their company name. Conditions like this are a very burdensome company, and the additional cost is often charged to farmers by pressing the price of cattle at the level of breeders. As a result, the margin received by farmers is getting smaller.

\section{CONCLUSION AND RECOMMENDATIONS}

The degree of concentration of beef cattle market shows a fluctuating movement from 2014-2017, but its movement is still on the market structure of moderate to strict oligopoly competition with a CR4 value between 0,50,9 -70,8 and HHI between 1,193,901 - 1,621,381. These findings indicate that the concentration of beef cattle market suggests market share satisfaction by some firms, leading to price regulation. The fluctuating trend in market concentration levels indicates a transactional horizontal transition to cattle delivery quotas out of Nusa Tenggara Timur that imply price regulation by oligopolists and can harm producers, consequently the market becomes inefficient.

This research gives a huge contribution to the business actors both producers (breeders), traders between the island and entrepreneurs, consumers in conducting buying and selling transactions. Similarly, the government in order to regulate the system and marketing mechanism so that more efficient through the regulation and supervision more stringent on all links of the beef cattle trading system. The weakness of this study is the limited time series of data in related parties, so the researchers present in the period of 4 years. But still gives a real picture of the dynamics of the degree of market concentration. Further research is needed by adding Gini Ratio, Rosenbluth Index and Entropy Index for comparison.

\section{REFERENCES}

1. Ayele, S; Zemedu, L; Gebremdhin, D. (2017). Analysis of Market Structure, Conduct and Performance of Beef Cattle: The Case of Dugda District, East Shoa Zone, Oromia Regional State, Ethiopia. Journal of Biology, Agriculture and Healthcare ISSN 2224-3208 (Paper) ISSN 2225-093X (Online) Vol.7, No.5, 2017

2. Ditjen PKH. (2007). Statistik Peternakan dan Kesehatan Hewan 2007. Direktorat Jenderal Peternakan dan Kesehatan Hewan. Kemtan RI.

3. Bosena, T., Bekabil, F., Gebremedhin, B., \& Hoekstra, D. (2011). Structure-conductPerformance of Cotton Market: the Case of Metema District, Ethiopia. 
4. Ginevičius, R., and Čirba, S. (2007). Determining Market Concentration. Journal of Business Economics and Management, 8(1), 3-10.

5. Gwin, C. R. (2001). A Guide for Industry Study and the Analysis of Firms and Competitive Strategy. Available from Internet:< http://faculty. babson. edu/gwin/indstudy/index. htm.

6. Kazemzadeh, E., \& Sheikh, Z. A. (2015). Sales Concentration Index in The Iranian Car Market. Industrija, 43(4), 129-149.

7. Lipczynski, J., Wilson, JO, Goddard, JA, \& Goddard, J. (2005). Industrial Organization: Competition, Strategy, Policy. Pearson Education Limited, Harlow..

8. Mohamed, Z. A., Kasron, N., Abd Latif, I., Sharifuddin, J., Rezai, G., \& Terano, R. (2015). Structure, conduct and performance of the Malaysian meat and meat preparation industry. Pertanika Journal of Social Sciences \& Humanities, 23(spec. June), 47-62

9. Naylah, M. (2010). Pengaruh Struktur Pasar Terhadap Kinerja Industri Perbankan Indonesia (Tesis Pasca Sarjana, Universitas Diponegoro).

10. Naldi, M., \& Flamini, M. (2014a). The CR4 Index and the Interval Estimation of the Herfindahl-Hirschman Index: an Empirical Comparison.

11. Naldi, M., \& Flamini, M. (2014b). Interval Estimation of the Herfindahl-Hirschman Index Under Incomplete Market Information. In Computer Modelling and Simulation (UKSim), 2014 UKSim-AMSS 16th International Conference on (pp. 318-323). IEEE.

12. Rhoades, S. A. (1993). The Herfindahl-Hirschman Index. Fed. Res. Bull., 79, 188.

13. Singh, V., \& Zhu, T. (2008). Pricing and Market Concentration in Oligopoly Markets. Marketing Science, 27(6), 1020-1035.

14. Werden, G. J. (1991). Horizontal Mergers: Comment. The American Economic Review, 81(4), 1002-1006. 